\title{
Alon Goshen-Gottstein Luther the Anti-Semite: A Contemporary Jewish Perspective
}

(Minneapolis: Fortress Press, 2018), softcover, xvi + 98 pp.

\author{
STEPHEN BURNETT \\ sburnett1@unl.edu \\ University of Nebraska, Lincoln, NE 68588
}

Alon Goshen-Gottstein, a Jewish scholar with extensive experience in interfaith education, has written an unusual book on Luther. He proposes that the study of Luther's antisemitism can be used as a vehicle for furthering dialogue between Jews and Christians. More broadly, Luther's views can aid analysis of where religions can "go wrong," especially when they express hostility toward religious others. He devotes roughly half of the book to evaluating Luther from several different perspectives: Luther as Jews perceived him (chapter 2), Luther within his historical context (chapter 3), and the internal coherence of Luther's anti-Jewish views within his theological framework (chapter 4). It is in the latter chapter that Goshen-Gottstein creates a "model" for evaluating where religious traditions generally can "go wrong" (p. 23).The criteria that he uses to evaluate Luther's antiJudaism includes "Lack of contact with Jews and no meaningful firsthand knowledge of Jews"; "Wrong and misleading knowledge and information"; "Personal hurt and offense as a consequence of deep religious engagement"; "Personal trauma and personal fears"; "Theological and scriptural foundations"; "Protecting Christian identity"; "the Apocalyptic dimension"; and "Disappointment with lack of Jewish conversions." He dismisses three further reasons for Luther's anti-Judaism as lacking plausibility: "Failing health"; "Acceptance of prevailing opinions"; and "Jews as stand-ins for papists" (pp. 26-48). The two remaining chapters contain Goshen-Gottstein's thoughtful application of these factors to extremist groups of modern Israeli Jews. He uses two examples: the arson attack on the pilgrimage church at Tabgha (the traditional site of Jesus' feeding of the five thousand) and some Jews praying anti-Christian versions of traditional Jewish prayers (pp. 5457). Finding these repugnant, he seeks in the book to apply reciprocally the lessons learned from Luther's antisemitism to these present-day Jews. 
Goshen-Gottstein's intended audience is interfaith educators like himself. He assumes a readership who acknowledge the legitimacy of other faiths and consequently condemn proselytism and missionizing of any kind (pp. 68, 88-89). He emphasizes the importance of interreligious contacts and friendships in order to replace false information and views with true ones, though he acknowledges such contacts by themselves are not inevitably successful (p. 70 n. 17). He understands biblical interpretation in the service of theological creativity as an activity requiring both tentativeness and a willingness to acknowledge the possibility of multiple interpretations (p. 83). Luther serves as an example for him. While Luther viewed his refusal to countenance the validity of Jewish biblical interpretations as the logical result of his theology, Goshen-Gottstein calls it a "failure of theological nerve" (p. 37).

Goshen-Gottstein's portrayal of Luther within his own place and time, and the role antisemitism played in his life, reflects an engagement with good contemporary scholarship on the subject. His insights into the personal factors in Luther's turn against Jews, such as his personal trauma from the failed "dialogue" with rabbis in Wittenberg in 1526, are fair ones, even if Luther's actual response to the conversation was disproportionate. However, his treatment of Luther is at times superficial and misleading. To begin with, the three factors that he cavalierly dismisses as implausible-Luther's failing health, his acceptance of prevailing opinions on Jews, and his purported use of Jews as stand-ins for papists - are actually all relevant to some degree for the fateful shift in his attitude toward Jews, or at least in the way Luther expressed himself. For example, Luther expressly said in his famous Galatians lectures of 1531 that the papists are "our Jews" (Luther's Works, vol. 26, p. 207). He repeatedly made the unflattering comparison throughout his mature works between the "Jews then" and the "papists now" to explain the maladies of the Catholic Church. While the author admits that some present-day Jews consider Christianity to be idolatrous and express this forcefully in prayer, he is unwilling to acknowledge fully that Luther was aware that Jews believed this in his day (pp. 30, 54-55). Interested readers should take Goshen-Gottstein's evaluation of Luther's antisemitism as at best a starting point for their study, not the final word on the subject.

Goshen-Gottstein's Luther the Anti-Semite is thought-provoking and to my knowledge unique for his efforts to make Luther's antisemitism into a kind of diagnostic tool for examining and predicting when religious traditions can turn hostile or even violent toward others. His prescriptions for identifying potential sources of conflict between Judaism and Christianity and possibly between other religious traditions are helpful for beginning fruitful conversations across religious lines. The book makes a contribution to the literature of interfaith dialogue, and especially the Jewish-Lutheran dialogue, rather than to scholarship on Luther and the Jews. 